\title{
PARETIC SYNDROME IN GULLS FROM SOUTHERN PORTUGAL: SEARCHING FOR THE CAUSATIVE AGENT
}

Begoña Ben-Gigirey ${ }^{1}$, María Casero ${ }^{2}$, Christelle Mazuet ${ }^{3}$, Pilar Riobó ${ }^{4}$, Francisco Rodríquez ${ }^{1}$ 1'nstituto Español de Oceanografía (IEO), Centro Oceanográfico de Vigo, Subida a Radio Faro 50, 36390, Vigo, Spain. ${ }^{2}$ RIAS Wildlife Rehabilitation and Research Centre, Parque Natural da Ria Formosa, 8700 - 194 Olhão, Portugal. ${ }_{3}^{3}$ Pasteur Institute, CNR Bactéries anaérobies et Botulisme, 25 rue du Dr Roux 75015 Paris, France. ${ }^{4}$ Instituto de Investigaciones Marinas, Consejo Superior de Investigaciones Cientificas (IIM-CSIC),36208, Vigo, Spain.

\section{INTRODUCTION} syndrome were received at RIAS Wildlife Rehabilitation and Research Centre of Ria Formos (Olhão, Faro). On admission 333 gulls were dead and 2099 were alive.

Clinical signs: different degrees of ascendant flaccid paresis, weakness, anorexia, diarrhea (flaccid cloacae), dyspnoea and, in some cases, death.

Dead animals were considered as paretic syndrome victims due to the presence of diarrhea, absence of injuries, the date of arrival concurring with a paretic syndrome outbreak and the necropsies findings. Admission numbers have been increasing every year, rocketing in 2019 (see Figures).

Gulls were classified in $\mathbf{5}$ different levels according to the symptoms severity (see Table). Treatment depended on the severity level and involved basic supportive care: fluid therapy, feeding assistance and treatment of secondary conditions until full autonomy was recovered.

What's the posible cause?

Several biotic contaminants could be the potential cause of this syndrome: marine biotoxins, Clostridium botulinum, cyanotoxins and virus. Other factors (starvation, abiotic contaminants, etc) could also contribute to the gulls death. The veterinary from RIAS contacted several research and mortality episodes. Pasteur Institute (Paris) and the Spanish Oceanographic Institute (IEO Vigo) agreed to perform toxin analyses.
Between 2010 and 2019, 2432 gulls (1125 Larus michahellis and 974 L. fuscus) with paretic Institutes seeking for collaborations that could help ascertain the reason of the continuous morbidity

\begin{tabular}{|c|c|c|c|}
\hline Level & Symptoms & Admission procedures & $\begin{array}{l}\text { Larus michahellis } \\
\text { and } L \text {. fuscus }\end{array}$ \\
\hline 1 & $\begin{array}{l}\text { - Unable to fly } \\
\text {-Weakness \& dropped wings } \\
\text {-Able to walk \& autonomously } \\
\text { feed } \\
\text {-Diarrhea }\end{array}$ & $\begin{array}{l}\text {-Subcutaneous fluid therapy } \\
\text { - Solid palatable food offered } \\
\text { - Water ad libitum }\end{array}$ & \\
\hline 2 & $\begin{array}{l}\text {-Half-standing } \\
\text {-Mild anorexia or feeding } \\
\text { autonomously } \\
\text {-Diarrhea }\end{array}$ & $\begin{array}{l}\text {-Subcutaneous fluid therapy } \\
\text { - Solid palatable food offered. If not } \\
\text { accepted tube feeding } \\
\text {-Water ad libitum }\end{array}$ & \\
\hline 3 & $\begin{array}{l}\text { - Hind limbs paralysis } \\
\text {-Mild dyspnoea } \\
\text {-Partial or complete third eyelid } \\
\text { paralysis } \\
\text {-Anorexia } \\
\text { - Diarrhea }\end{array}$ & $\begin{array}{l}\text {-Subcutaneous fluid therapy } \\
\text { - Tube feeding until solid food } \\
\text { accepted } \\
\text {-Water ad libitum }\end{array}$ & \\
\hline 4 & $\begin{array}{l}\text {-Severe dyspnoea } \\
\text {-Complete third eyelid paralysis } \\
\text { - Legs \& neck paralysis } \\
\text {-Anorexia } \\
\text { - Diarrhea }\end{array}$ & $\begin{array}{l}\text { - Subcutaneous and intravenous } \\
\text { fluid therapy } \\
\text { - Repeat fluid therapy for } 24 \text { or } 48 \\
\text { hours until tube feeding is safe }\end{array}$ & \\
\hline 5 & $\begin{array}{l}\text {-Irreversible \& severe full body } \\
\text { paralysis } \\
\text {-Severe inability to breath } \\
\text {-Diarrhea } \\
\text {-Quick death }\end{array}$ & $\begin{array}{l}\text { - Subcutaneous and intravenous } \\
\text { fluid therapy } \\
\text { - Repeat fluid therapy for } 24 \text { or } 48 \\
\text { hours until tube feeding is safe }\end{array}$ & \\
\hline
\end{tabular}

\section{OBJECTIVES}

The aim of this preliminary study was to evaluate if Amnesic Shellfish Toxins (Domoic acid, (DA)), Paralytic Shellfish Toxins (PSTs) or botulinum toxins could be the cause of the gulls paretic syndrome. This presentation compiles the results of the Clostridium botulinum and marine biotoxins analysis conducted at the French National Reference Centre for anaerobic bacteria and botulism, Pasteur Institute (Paris) and the Vigo Centre of the Spanish Oceanographic Institute, respectively.

\section{METHODS \& RESULTS}

\section{Paralytic Shellfish Toxins analyses}

- Gulls samples: ten kidneys \& contents from one cloacae.

- Drawbacks: very small sample size, difficult homogenization, extraction had to be scaled down.

- Double extraction with $0.1 \mathrm{M} \mathrm{HCl}$. Sample deproteination with trichloroacetic acid.

- Analyses by Liquid Chromatography with Postcolumn Derivatization \& Fluorescence Detection.

- Samples re-run without oxidation: checking for

GTX1, GTX2, GTX3, GTX4, dcGTX2, dcGTX3, GTX5, dcSTX, STX were not detected in any of the samples tested naturally fluorescent compounds needed
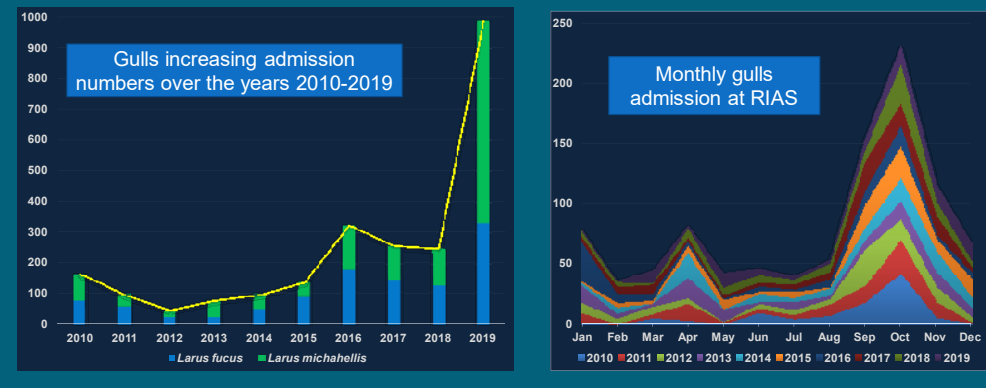

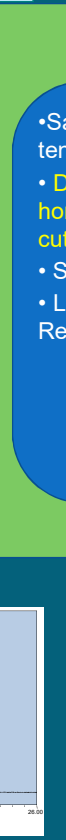

Naturally fluorescent compound. Sample non oxidized.

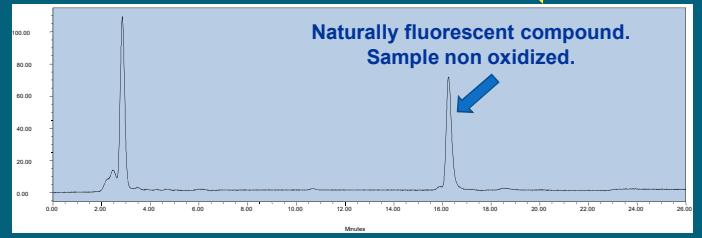

\section{Domoic acid analyses}

-Samples: twenty three gull samples: ten livers, ten intestines and three cloacae contents.

- Drawbacks: small sample size, difficult homogenization (specially for intestines, hard to cut by Ultraturrax, pre-cutting needed.

- Single dispersive extraction: with MEOH 50\%

- Liquid Chromatography coupled to High

Resolution Mass Spectrometry.

DA was not detected in any of the samples tested
Clostridium botulinum analyses

\section{CONCLUSIONS}

- Domoic acid and Paralytic Shellfish Toxins do not seem to be the cause of the gulls paretic syndrome.

- Samples tested point to Clostridium botulinum as the possible cause of the gulls paretic syndrome, or at least one of the causes. This bacterium is considered as a frequent cause of massive mortality events in seabirds. The symptoms caused in seabirds are very similar to the ones produced by PSTs.

- Further studies are needed to evaluate the source of $C$. botulinum contamination

- Additional studies are planned in other Institutions to evaluate the potential implication of Cyanotoxins and Tetrodotoxins in the toxic episodes.

\section{REFERENCES}

De La Iglesia, P.; Barber, E.; Giménez, G.; et al. High-throughput analysis of amnesic shellfish poisoning toxins in shellfish by ultra-performance rapid resolution LC-MS/MS. J. AOAC Int. 2011, 94, 555-564.

Gibble, C.M.; Hoover, B. Interactions between Seabirds \&Harmful Algal Blooms. In Harmful Algal Blooms: A Compendium Desk Reference; S.E. Shumway, J.M. Burkholder \& S.L. Morton Eds; John Wiley \& Sons Ltd. 2018; pp. 223-242.

Mazuet C. Sautereau J., et al. An atypical outbreak of food-borne botulism due to Clostridium botulinum types B and E from ham. J Clin Microbiol. 2015, 53:722-726.

Rourke, W.A.; Murphy, C.J.; Pitcher, G.; Van De Riet, J.M.; et al. Rapid postcolumn methodology for determination of paralytic shellfish toxins in shellfish tissue. J. AOAC Int. 2008, 91, 589-597.

Rodriguez, F.; Garrido, J.L.; Sobrino, C.; Johnsen, G.; Riobó, P.; et al. Divinyl chlorophyll a in the marine eukaryotic protist Alexandrium ostenfeldii (Dinophyceae). Environ. Microbiol. 2016, 18, 627-643.

Sonne, C.: Alstrup, A.K.O.: Therkildsen, O.R. A review of the factors causing paralysis in wild birds: Implications for the paralytic syndrome observed in the Baltic Sea. Sci. Total Environ. 2012, 416, 32-39.

Van Hemert, C. Schoen, S.K. Litaker. R.W.S Smith, M. M : et al. Algal toxins in Alaskan seabirds: Evaluating the role of saxitoxin and domoic acid in a large-scale die-off of Common Murres. Harmful Algae 2020 , $22,101730$.

Vanhomwegen J, Berthet, N. Mazuet, C.; et al. Application of high-density DNA resequencing microarray for detection and characterization of botulinum neurotoxin-producing clostridia. PLoS One 2013, 8:e67510 